\title{
Urbanisation and Growth Linkage in in China
}

\author{
Dr. Kabita Kumari Sahu \\ Lecturer in Economics North Orissa University Baripada, Orissa, India
}

\begin{abstract}
The paper seeks to analyse the trend, pattern and process of urbanization in China based on secondary data from 1975 to 2011 ( 37 years) collected from Chinese Statistical Year book(CSY), World Development Indicators(WDI), Asian Development Bank (ADB) Reports and research reports. The study has used least square regression model, regression between growth of urbanization and growth of per capita GDP, Augmented Dicky-fuller test for stationarity \& stability of time series data, ganger causality test and vector auto regression models \& graphs. The paper focuses on pattern of urbanization in following three phases.

(i) Urbanization driven by industrialization (1978 to 1987)

(ii) Urbanization driven by land and housing reform (1988 to 2000)

(iii) Urbanization driven by the service industry (2001 to 2011)

The linkage between growth of urbanization and growth of real per capita GDP is not significant for the current years but growth of urbanization in China has significant linkage with past Per capita GDP growth which implies feed back effects and unidirectional relation as per VAR models.
\end{abstract}

Key Words- Causality, Growth, Urbanisation, , Linkage, Trend

JEL- O18, P25

\section{Introduction}

The process of urbanization in China is a longstanding issue of academic interest. China was a predominantly rural society till 1978. Since economic reforms in 1978, the last three and half decades have witnessed an extraordinary turnaround in China's perspective on urbanization, as well as massive urban growth. Many researchers on urbanization in China believe that China has been under-urbanized as compared with other countries at similar development level, but that, in recent years, China has rapid urbanization compared to other countries. China's urbanization emerged and grew only in the late period of reform, despite the mass migration from rural areas to urban areas. Urbanisation and economic growth are closely inter linked. It is generally accepted that urbanization accompanies economic growth and development even if scholars disagree about the direction of causality. Economic growth promotes the expansion of modern industries and changes the structure of the economy; as a result, populations move from the agriculture-dominated rural areas to industry- and service-dominated urban areas (Henderson,1988, Todaro,1997). On the other hand, urbanization also promotes economic growth. Densely populated and business- and manufacturing-concentrated urban areas offer economies of scale and agglomeration economies by lowering transportation costs and promoting knowledge and network spillovers. Empirical tests have confirmed the strong correlation between urbanization and GDP per capita in many countries(Henderson, 2000).In this context, the objective of the paper is to analyse process, pattern of urbanization in China and to investigate the linkage between urban growth rate and GDP growth rate in China during 1978 to 2011 using econometric techniques. It attempts to quantify important trends in the Chinese process of urbanization using graphical presentation and least square models.

\section{Literature Review}

There is vast literature on growth and pattern of urbanization in China. An attempt has been made to review few important research studies and to identify research gap. Moomaw and Shatter (1996) in their study found that industrialization, export orientation and foreign assistance influence the path of urbanization. Zhang (2003) in his study concludeed that China has been transforming from a rural to an urban economy especially since 1978 when economic reforms were initiated and rapid economic growth began. Petrakos and Brada (1989) stated that authoritarian regimes tend to be less sensitive to the safety and welfare of rural residents, thus resulting in a higher urbanization level as rural residents seek the safety and public services available in urban areas. They also found that political instability influences urbanization levels because unstable regimes often attempt to placate urban populations in order to avoid popular resistance in those cities where the members of the ruling elite live and work, resulting in a pro-urban bias. Thus, there are many potential explanatory variables for the level of urbanization, but the level of economic development measured by per capita GDP is the most significant one. Study by Henderson(1988) and Todaro(1997) mentioned GDP per capita explains as much as $75 \%$ of the variation in the urbanization level in a large sample of countries. On the other hand, urbanization 
also promotes economic growth. Densely populated and business and manufacturing concentrated urban areas offer economies of scale and agglomeration economies. Empirical tests have confirmed the strong correlation between urbanization and GDP per capita (Henderson, 2000). In addition to per capita income, structural and non-economic factors also accelerate or retard urbanization (e.g., Henderson, 2003). Liu et al. (2003) stated that China has been relatively under-urbanized compared to its level of industrialization or to other developing countries at similar stages.

Li and Chen (2001) used a cross-country econometric model to study the relationship between income and urbanization and argued that China's urbanization was initially about 10 percentage points below that of other comparable countries and that China has been closing the gap during the past 20 year reform period. Ebanks and Cheng (1990) concluded that urbanization on a significant scale began quite late in China, and the level is still comparatively low at present although China has quickly caught up with developing countries within a short period of time . One set of explanations focused on the effects of China's development strategy, which sought to maximize the pace of industrialization by reducing the need for large investments in urban infrastructure by minimizing urbanization (Kirkby, 1985; Chan, 1992). This explanation was criticized by scholars who stressed the importance of ideological factors in fostering an anti-urban development policy, such as the ideological bend of Mao and of the Communist Party hierarchy and of broader cultural biases against urban intellectuals (Ma, 1977; Lo, 1987; Tang, 1997) or of systemic factors (Zhang and Zhao, 2003). Zhang and Song (2003) stated that the chief instrument for the realization of these policies was the hukou (household registration) system, which was imposed shortly after the Chinese Communist Party took power. Hukou has restricted free migration from rural to urban areas, but, since the reform started in 1978, the restriction on migration to urban areas has been gradually relaxed. As a result, 60-100 million rural workers are now working in the cities on a temporary basis. Parallel to this change, the strict policy constraining city size that was implemented in Mao's era has also been eased and urbanization has accelerated.

\section{Urbanization in China in Pre-Reform Period (1949-1978)}

China was a rural society in pre reform period and its large population was engaged in labor-intensive agriculture. In 1949 only 10.6 percent of the total population lived in cities (Li and Pichaud, 2006). In the subsequent thirty years till 1978, prior to reform, urbanization rates remained relatively low despite China's intensive growth strategy that advocated the development of heavy industry and similar investments in capitalintensive goods. China's urbanization rate in terms of population increased by only 8.8 percent between 1949 and 1980 with an average annual growth rate of only 0.28 percent (Li). During this period, state planners enjoyed almost complete control over population migrations and urban development. The rigid household registration system (hukou) in China prohibited unauthorized household relocation or labor migration, allowing the State to control the size and growth of towns and cities (Zhang, 2002). Industrialization did yield modest urban population growth during the pre-reform period. The stringent controls on population movement and the policy emphasis on the development of small towns and cities, the urban population increased only to 17.9 percent of China's population by 1978 (Li).

\section{Stage -I Urbanization driven by industrialization during 1978 to 1987}

In 1978, a new economic policy and massive reforms were adopted in China under which communally owned farmland was divided into individual plots. The People's Commune System (PCS) collapsed and the Household Responsibility System (HRS) was established which allowed individual households to take full charge of production on their allocated land plots. Households were allowed to retain food surpluses instead of turning in the entire farm product to the collectives under the PCS (Yang, 1996). The initiatives of peasants galvanized rural productivity and generated a huge surplus of farm labourers that had been disguised under the PCS. According to an estimate by Taylor and Banister, the number of surplus rural workers exceeded 100 million each year between 1982 and 1987, accounting for 33.5 to 42.5 per cent of the entire rural labour force (Ma and Lin, 1993). In the early 1980s, holders of an agricultural hukou were allowed to migrate to nearby market towns and other small towns, as long as they could provide for their own livelihood (Chan, 2009). This loosened the main constraint on migration. Subsequent industrialization in these towns absorbed the labour surplus released from the countryside. The rural industrialization was promoted through the promotion of township and village enterprises (TVEs) which were set up in rural areas where the administrative levels are township and village. The main driving forces behind growth of village industries are as follows-

(i) The initiative of the local government for promoting tax revenue

(ii) The central government's aspiration to modernize national agriculture

(iii) The absorption of surplus labour

(iv) The alleviation of rural poverty by improving the living standards of the peasants

(v) The desire of those without adequate agricultural work to seek new opportunities for moving out of poverty 
(vi) underemployment in the countryside (Liang, 2006).

(vii) The existence of traditional craft activities, or favourable locations for foreign capital investment (Friedmann, 2004)

The number of people employed in TVEs grew rapidly from the early 1980s until the mid-1990s with over 100 million employees joining TVEs during that period. In comparison to the stagnant or even retrograde situation in state- and collectively owned enterprises during the same period, TVEs contributed significantly to employment creation. The TVE sector thus became one of the main pillars of China's economy. In 1990, rural industries accounted for a quarter of China's total GNP and 60 per cent of its rural production. Ninety million people were registered as rural-industry employees, and the actual number may have been much higher. Rural industries employed 87 per cent as many people as state sectors, although three years later, in 1993, these two sectors provided equal numbers of jobs (White, 1998). The development of rural industries enabled millions of former farmers to continue living close to their home villages. Despite their non-agricultural jobs, these workers maintained ties with farming and could provide support in the busiest farming seasons when mass farm labour was needed for short periods. In addition, the partially reformed hukou system continued to put restrictions on migration, and was another reason for people working in the towns close to their villages (Goldstein, 1990; Chan, 1994; Shen, 1995; Chan and Zhang, 1999; Solinger, 1999). The influx of rural workers (although most of them were temporary migrants) began giving an urban character to some rural areas through the development of rural industries (Friedmann, 2004). People in China moved from underemployment in the primary sector to engage themselves in the secondary (manufacturing industry, construction), and tertiary sectors (trades and services).

Ma and Lin (1993) and Ma and Fan (1994) explained the urbanization through rural industrialization as urbanization from below. Various local endowments led to the emergence of different models of rural-urban development. The sporadic industrial development in rural areas generated multi-centric urban spatial forms and the rampant growth of periphery of urban areas around medium-sized and large cities (Friedmann,2004). Initially, rural reform generated surplus rural labour and supplied sufficient farm produce to sustain nonagricultural activities in towns and cities. Further, changes in the hukou system facilitated rural migration to small towns. Then, local initiatives together with local endowments (such as the entrepreneurship of local leaders and technical knowledge) and foreign capital, all helped rural industries to flourish. The sector not only absorbed surplus labour but also contributed to the country's economy significantly throughout the 1980s. Moreover, the growth of rural industries spurred the development of small towns and cities and made those previously rural settlements increasingly urban. The urbanization process in this stage can thus be summarized as an endogenous and spontaneous growth of rural industries in small towns, leading to the urbanization of the countryside. This can be described as first stage of urbanization in China driven by industrialization and level of urbanization is shown below in table-1.

Table-1 Level of Urbanisation and per capita GDP during 1978 to 1987 ( Stage-1)

\begin{tabular}{|l|c|c|c|l|}
\hline Year & $\begin{array}{l}\text { Urban } \\
\text { population( } \\
\text { million) }\end{array}$ & $\begin{array}{l}\text { Growth Rate of Urban } \\
\text { Population(\%) }\end{array}$ & $\begin{array}{l}\text { Urban residents as \% of } \\
\text { total }\end{array}$ & $\begin{array}{l}\text { Real GDP } \\
\text { growth } \\
\text { rate(Annual \% } \\
\text { change) }\end{array}$ \\
\hline 1978 & 172.45 & ----- & 17.92 & 11.7 \\
\hline 1979 & 184.98 & 7.27 & 18.96 & 7.6 \\
\hline 1980 & 191.40 & 3.47 & 19.39 & 7.8 \\
\hline 1981 & 201.71 & 5.39 & 20.16 & 5.2 \\
\hline 1982 & 214.80 & 6.49 & 21.13 & 9.1 \\
\hline 1983 & 222.74 & 3.69 & 21.62 & 10.9 \\
\hline 1984 & 240.17 & 7.83 & 23.01 & 15.2 \\
\hline 1985 & 250.94 & 4.48 & 23.71 & 13.5 \\
\hline 1986 & 263.66 & 5.07 & 24.52 & 8.8 \\
\hline 1987 & 276.74 & 4.96 & 25.32 & 11.6 \\
\hline ADF Test & Stationary & & & \\
\hline Mean & 221.96 & 5.14 & 21.57 & 10.14 \\
\hline SD & 35.16 & 1.52 & 2.51 & 3.01 \\
\hline
\end{tabular}

Source- Chinese Statistical Year Book, various Years \& Author's Calculation

The average growth rate of urban population was $5.14 \%$ with standard deviation of 1.52( Table-1). Highest growth rate of urban population was $7.83 \%$ in 1984 followed by $7.27 \%$ in 1979 and it was lowest i.e, 3.47 in 1980. Urban resident as percentage of total population increased continuously with standard deviation of 2.51 . The average real GDP growth rate was $10.14 \%$ with standard deviation of 3.01 and it was highest i.e, $15.2 \%$ in 
1984. This is interesting to note that growth rate of urban population and Per capita GDP are both highest in 1984.

Least Square Trend equation of growth of Urban Population in Stage-1

A linear regression model was fitted to time series data on urbanization in all three stages. A similar model model has been used by Shenghe Liu, Xiubin Li, Ming Zhang ( 2003) in their study.

$$
\mathrm{U}_{\mathrm{t}}=\mathrm{a}+\mathrm{bt}
$$

where $\mathrm{U}_{\mathrm{t}}=$ urban population in million( Dependent Variable), $\mathrm{t}=$ Year( Independent Variable)

During stage-1, from 1978 to 1987 , the regression equation is as follows-

$\mathrm{Y}=159.09+11.35 \mathrm{t} \quad\left(\mathrm{t}-\mathrm{V}\right.$ alue $\left.=31.25, \mathrm{SE}=0.36 \& \mathrm{R}^{2}=0.99\right)$

The time series data of urban population is stable and stationary having no unit root(Table-1) according to Augmented Dicky-Fuller Test(ADF). The urban population in million in China is shown in bar diagram in Fig1.

Fig-1 Bar diagram of Urban Population in China during 1978 to 1987

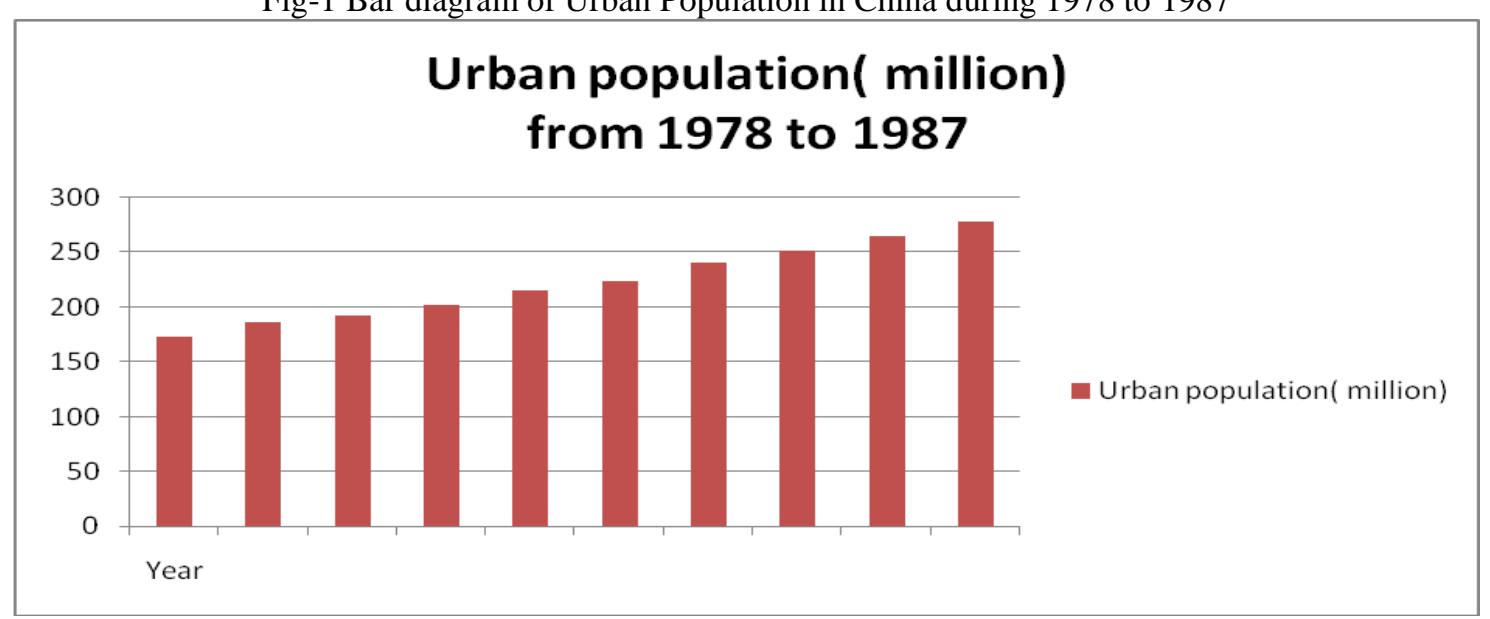

Urbanisation and Growth Linkage in Stage-1

China adopted economic reform and opening policy in 1978 deviating gradually from its traditional path of socialism and adopting aspects of a market-orientated economic system. In the subsequent years, China emphasized raising personal income and consumption and introducing new management systems to help increase productivity, the living standard, and technological quality. Reform began in the agricultural, industrial, fiscal, financial, banking, regulatory and labor systems. The decision to allow direct foreign investment was extremely successful in attracting foreign capital to China, initially in several small "special economic zones" along the coast, then spreading to 14 coastal cities and 3 coastal regions. The inflow of international capital greatly stimulated Chinese economic growth, particularly in the areas of international trade, the infrastructure, the transfer of technology and managerial know-how, human resources, and the increase in personal incomes. Urbanization in China increased significantly with the rapid economic growth since 1978. It was a function of the surpluses produced from the agricultural sector, massive employment opportunities created by the influx of direct foreign investment, tremendous economic growth and higher wage rate in cities. An attempt was make to study the linkage between growth of urbanization and growth of per capita GDP in China. A simple linear regression model used is as follows.

$\mathrm{UG}_{\mathrm{t}}=\mathrm{a}+\mathrm{b} \mathrm{GGDP}_{\mathrm{t}}$

Where $\mathrm{UG}_{\mathrm{t}}=$ Annual percentage growth rate of Urbanisation( Dependent Variable)

$\mathrm{GGDP}_{\mathrm{t}}=$ Growth rate of per capita GDP ( Independent Variable)

The equation obtained on the basis of time series data during Stage-1 is as follows

$\mathrm{UG}_{\mathrm{t}}=4.59+0.08 \mathrm{GGDP}_{\mathrm{t}}$

$\left(\mathrm{t}=0.45, \mathrm{SE}=0.18, \mathrm{R}^{2}=0.03\right)$

The regression coefficient is not significant which indicates that growth rate GDP is not the significant factor driving urbanization. Ganger Causality test \& vector auto regression model was tried with pooled data only for the robustness of the results. Extremely low value of $\mathrm{R}^{2}=0.03$ indicates that there are other important variables influencing urbanization in China in first stage. The line graph showing the trend of growth rates of urban population and per capita real GDP is shown in fig-2. 
Fig-2 Line graph showing movement of growth rate of urbanization \& per Capita GDP

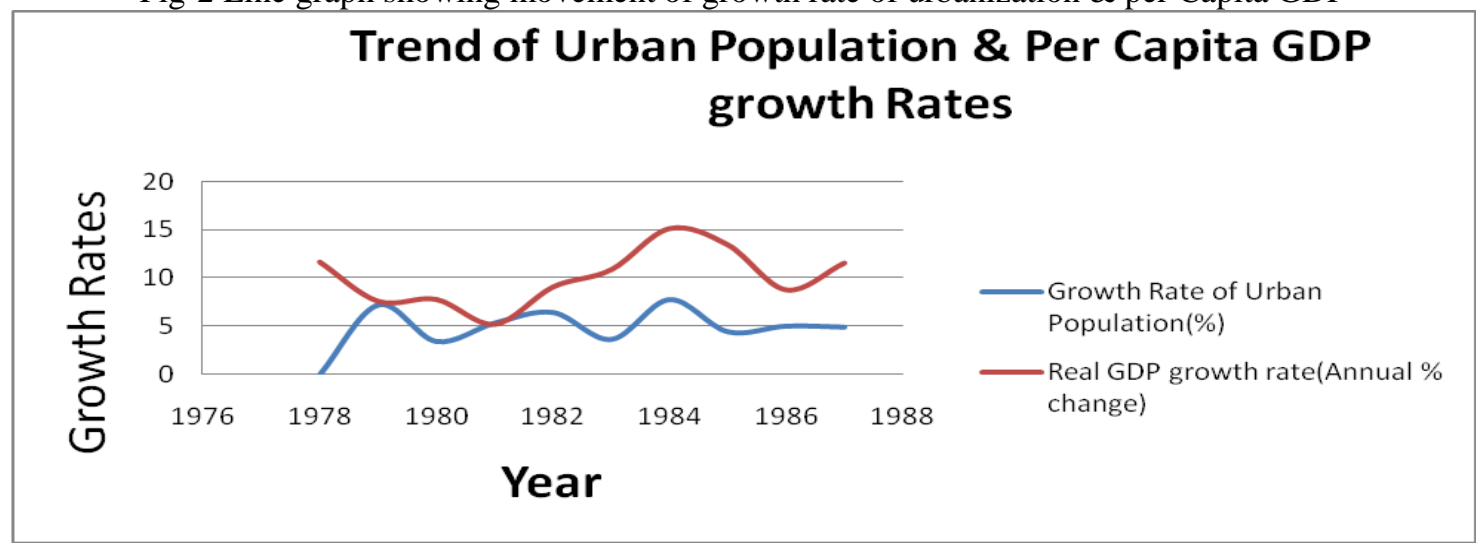

\section{Stage -II Urbanization driven by Land and housing reforms during 1988 to 2000}

The rural reform since the late 1978 was successful which encouraged the central government to promote further reforms in the urban sector through a series of policies adopted since 1984. The Chinese planned economy was transformed towards a market economy, cities were directed towards commercialization and privatization. Private property and other institutional arrangements, such as devolution of power, are essential in the process of marketization. The globalizing world, specifically in the forms of foreign trade and foreign capital, also fuelled the transformation. The key factor triggering these processes was land reform, which led to the commodification of the built environment. Since the economic reform, labour had been commoditized through certain migration rights, and attracted to towns and cities. Favourable policies facilitated foreign capital investment in selected regions and industries. Out of three factors of production, such as labour, capital and land, land only remained intact in the state's domain. Due to official land reform, several coastal cities with concerns about land use for foreign investors began to experiment with the paid use of urban land. Shenzhen, one of the Special Economic Zones established in the early 1980s, was the first to levy an annual land-use fee to overseas investors (Yeh, 1985). Charging land-use fees was then introduced in 1984 (Xie, Parsa et al., 2002). Such trials confirmed the irrational and inefficient land use under the previous system, and triggered the establishment of the State Land Administration Bureau and the enactment of Land Administration Law in 1986. The Bureau was responsible for, and in charge of land policy reform, land allocation and acquisition, monitoring of land development, comprehensive land-use plans, and implementation of land laws (Ding, 2003). The law shifted power in land management from various ministries and other units to the local government. The objectives of the reform were to promote local productivity, increase local initiatives in expanding revenue and cutting expenditure, and develop the national economy. Local governments were permitted to retain certain revenues for local disposal. Land revenue was included in the category of extrabudgetary revenue. Together with the disposal rights of land granted by Land Administrative Law, the role of local government started to change, gaining autonomy and initiative (Oi,1995). Walder (1995) referred to local governments as "industrial firms" and Duckett (1996) and Friedmann (2004) described them as entrepreneurial states (or cities). Land was the essential instrument in developing the local state. Housing reform started in late 1980 during which the significance of land was again emphasized. The gradual reform of the housing sector started when the state faced a severe housing shortage and an insufficient budget to construct more housing stock (Wu, 1996; Zhou and Logan, 1996).

Table-2 Urbanisation level and growth rates of per capita GDP during 1988 to 2000( Stage-II)

\begin{tabular}{|l|c|l|c|l|}
\hline Year & $\begin{array}{l}\text { Urban population } \\
\text { (million) }\end{array}$ & $\begin{array}{l}\text { Growth Rate of } \\
\text { Urban } \\
\text { Population(\%) }\end{array}$ & $\begin{array}{l}\text { Urban residents as \% } \\
\text { of total }\end{array}$ & $\begin{array}{l}\text { Real GDP growth } \\
\text { rate(Annual \% change) }\end{array}$ \\
\hline 1988 & 286.61 & 3.57 & 25.81 & 11.3 \\
\hline 1989 & 295.40 & 3.07 & 26.21 & 4.1 \\
\hline 1990 & 301.91 & 2.20 & 26.41 & 3.8 \\
\hline 1991 & 305.43 & 1.16 & 26.94 & 9.2 \\
\hline 1992 & 323.72 & 5.99 & 27.46 & 14.2 \\
\hline 1993 & 333.51 & 3.02 & 27.99 & 13.5 \\
\hline 1994 & 343.01 & 2.85 & 28.51 & 12.6 \\
\hline 1995 & 351.74 & 2.54 & 29.04 & 10.5 \\
\hline 1996 & 373.04 & 6.05 & 30.48 & 9.6 \\
\hline 1997 & 394.49 & 5.75 & 30.91 & 8.8 \\
\hline \hline \multicolumn{5}{|l}{ www.iosrjournals.org } \\
\hline
\end{tabular}




\begin{tabular}{|l|c|c|c|l|}
\hline 1998 & 416.08 & 5.47 & 33.35 & 7.8 \\
\hline 1999 & 437.48 & 5.14 & 34.78 & 7.1 \\
\hline 2000 & 459.06 & 4.93 & 36.22 & 8.0 \\
\hline ADF & Stationary & & & \\
\hline Mean & 355.49 & 3.98 & 29.55 & 9.26 \\
\hline SD & 56.53 & 1.64 & 3.40 & 3.22 \\
\hline
\end{tabular}

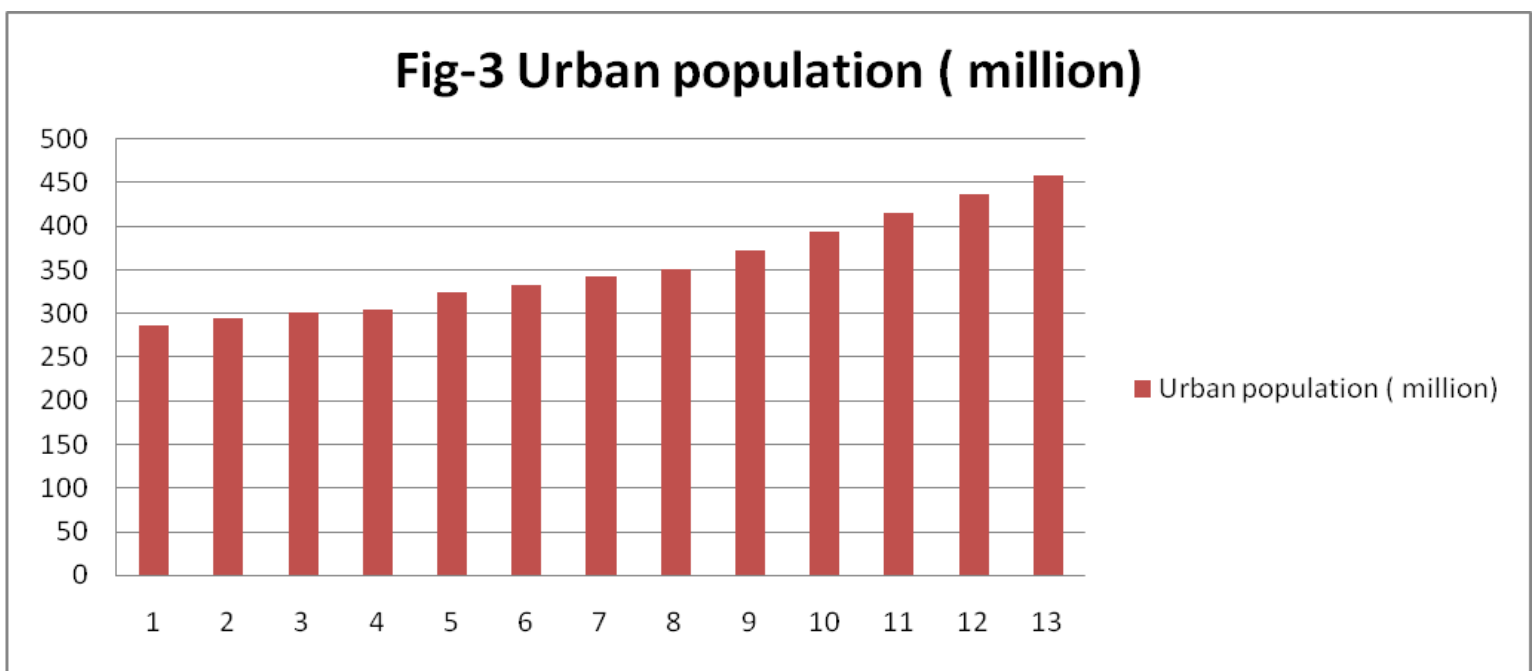

Source- Chinese Statistical Year Book, various Years \& Author's Calculation

With the announcement of gradual reform (State Council, 1988), the work-units started to sell existing housing stock, which triggered the process of housing commercialization. Later, state employees were subsidized by their work-units to buy newly developed housing. It was not until 1998 that the allocation of housing based on the state work-units was abolished. The objective of housing reform was to develop commodity housing to boost domestic demand and thus to stimulate economic growth. Hence the urbanization during second stage was mainly due to land and housing reform. The level of urbanization is analysed with time series data which shows that urban population in million ig growing continuously and series is stationary and stable with no unit root as per Augmented Dicky Fuller test. The average urban growth rate of population in second stage is $3.98 \%$ which is less than first stage. It implies that China had rapid urbanization in during 1978 to 1987 compared to 1988 to 2000 . The average real GDP growth rate during this stage is $9.26 \%$ ( Table-2) which lower than stage-1. The highest growth rate of urban population was $6.05 \%$ in 1996 but highest per capita GDP growth rate of 14.02 was found in 1992. The urban population during stage - II is shown in bar diagram in Fig-3.

\section{Least Square trend equation of Urban Population from 1988 to 2000 ( Stage-II)}

The least square trend was found during second stage using following linear trend equation.

$\mathrm{U}_{\mathrm{t}}=\mathrm{a}+\mathrm{bt}$

where $\mathrm{U}_{\mathrm{t}}=$ urban population in million( Dependent Variable), $\mathrm{t}=$ Year( Independent Variable)

$\mathrm{Y}=256.04+14.21 \mathrm{t}$

$\left(\mathrm{t}=15.87, \mathrm{SE}=0.89, \mathrm{R}^{2}=0.96\right)$

The slope or coefficient is significant \& positive with high value of $\mathrm{R}^{2}$ and higher value of coefficient than stage- 1 .

\section{Urbanisation and Growth Linkage in Stage-II}

The relation between urbanization and growth was tested using a linear regression model as described in stage-I. The result obtained is as follows.

$\mathrm{UG}_{\mathrm{t}}=3.38+0.06 \mathrm{GGDP}_{\mathrm{t}} \quad\left(\mathrm{t}=0.42, \mathrm{SE}=0.15, \mathrm{R}^{2}=0.02\right)$

The coefficient is not significant and value of $\mathrm{R}^{2}$ is very low. Hence there is positive but insignificant relation between growth of urban population \& growth of Per capita GDP during 1988 to 2000. The line graph of growth rates are shown below in graph -4 . 
Fig-3 Line graph of growth rates of Urban population and Per capita

GDP

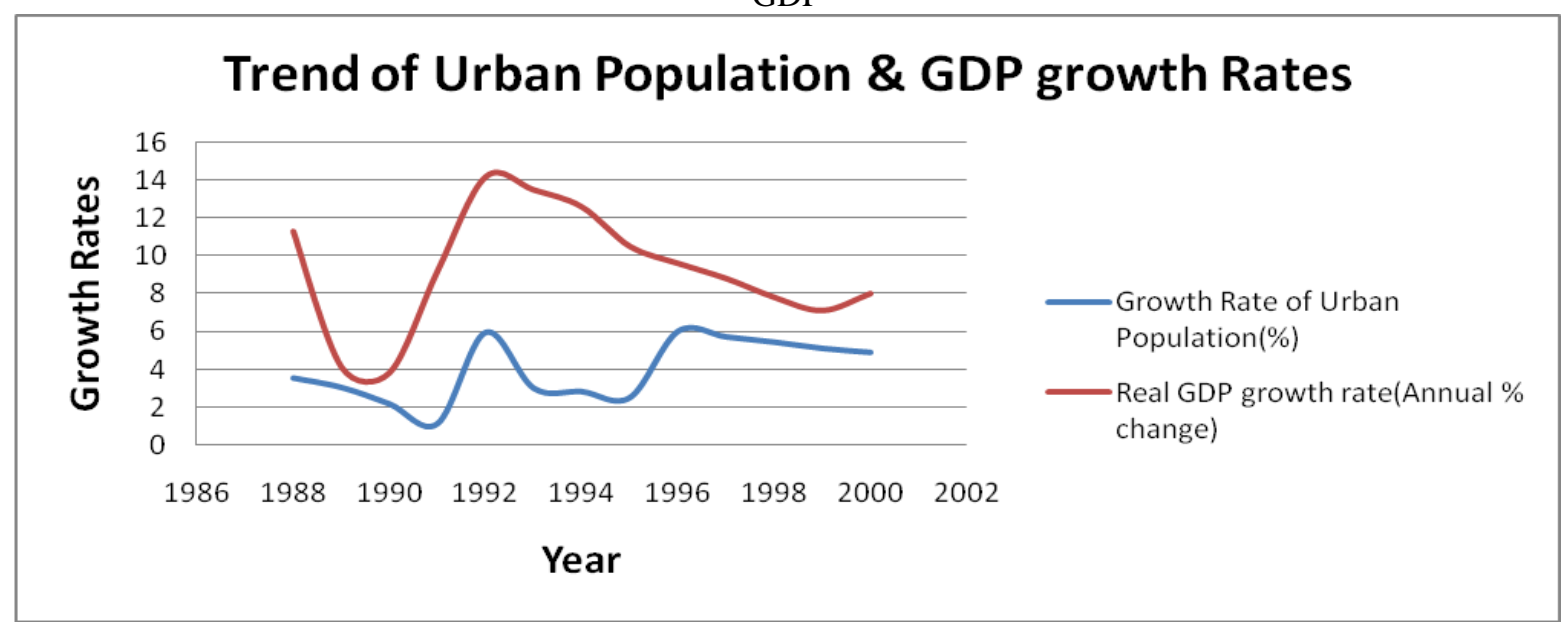

\section{Stage - III Urbanization in China driven by the service industry during 2001 to 2012}

The urbanization in China was driven by growth of service sector during 2001 till now. The growth of the tertiary-sector industries in China had been limited for decades because services were considered unproductive and consumptive. In the early stages of economic reform, manufacturing and other secondary industries were emphasized to boost the country's economy. The role of the tertiary sector was not taken seriously until 1992, when the central government proposed a strategy to facilitate its development. This shift was based on the awareness that the service industry can give cities a competitive edge and impetus for new growth. Service Sector would help to diversify the employment structure, open up new opportunities for lowthreshold entrepreneurship, and generate employment. In addition, the growth of per capita income of urban residents since the early 1990s required a dynamic service sector. Per capita income had grown more than tenfold in less than two decades. In this period, the service sector consisted mainly of consumer-related services, such as wholesale and retail trade, hotels and catering. In urban China, the service sector grew rapidly. The contribution of the tertiary industry to employment increased from 30 to 50 per cent from 1995 to 2000 , and tertiary-generated GDP maintained around 40 per cent of all GDP in this period. Since 2000, in terms of both GDP and employment, the service industry has been increasing with industry.

Recently the producer service sector developed in China since the privatization of the public ownership enterprises. Thus, there was little demand for externalizing separate functions to outside service providers. Furthermore, human resources with high levels of education and specialized talents were not yet ready for producer services. Since the 10th Five-Year Plan (2001-2005), the modern service sector in China, designated to play a significant part in enhancing the global competitiveness of the Chinese urban economy. The advanced producer service sector in China normally refers to services for businesses, such as computer services, legal consulting, accounting, marketing, advertising, scientific and research services. The finance and real-estate sectors had the greatest growth momentum. Producer services are predicted to grow in the coming decades. This policy emphases have been reflected in the development of almost all major cities. The development outlines of China's two major city regions endorsed recently by the National Development and Reform Committee (NDRC) reflected the determination of both central and local governments to promote the producer service sector. The overall goal of the development of the producer service industry is to account for more that 60 per cent of service output by 2020.The urban population, growth rates of urban population and GDP are given below in table-3.

Table-3 Urbanisation Level and growth rates during 2001 to 2011 in Stage-III

\begin{tabular}{|l|l|c|c|l|}
\hline Year & $\begin{array}{l}\text { Urban } \\
\text { population( } \\
\text { million) }\end{array}$ & $\begin{array}{l}\text { Growth Rate of Urban } \\
\text { Population(\%) }\end{array}$ & $\begin{array}{l}\text { Urban residents as \% of total } \\
\text { Population }\end{array}$ & $\begin{array}{l}\text { Real GDP } \\
\text { growth } \\
\text { rate(Annual \% } \\
\text { change) }\end{array}$ \\
\hline 2001 & 486.04 & 5.88 & 37.66 & 8.3 \\
\hline 2002 & 502.12 & 3.31 & 39.09 & 9.1 \\
\hline 2003 & 523.76 & 4.31 & 40.53 & 10.0 \\
\hline 2004 & 542.83 & 3.64 & 41.76 & 10.1 \\
\hline 2005 & 562.12 & 3.55 & 42.99 & 9.9 \\
\hline 2006 & 577.06 & 2.66 & 43.90 & 11.1 \\
\hline
\end{tabular}




\begin{tabular}{|l|c|c|c|l|}
\hline 2007 & 593.79 & 2.89 & 44.94 & 11.4 \\
\hline 2008 & 606.67 & 2.17 & 45.68 & 9.6 \\
\hline 2009 & 628.02 & 3.52 & 46.59 & 8.7 \\
\hline 2010 & 665.57 & 5.98 & 49.90 & 10.4 \\
\hline 2011 & 690.80 & 3.79 & 51.20 & 9.4 \\
\hline ADF & Stationary & & & \\
\hline Mean & 579.89 & 3.79 & 44.02 & 9.82 \\
\hline SD & 65.25 & 1.21 & 4.24 & 0.94 \\
\hline
\end{tabular}

Source- Statistical year Book, China various years and Author's calculation

The urban population has continuously increased during this period \& the time series is also stationary and stable as tested by $\mathrm{ADF}$ test. The average growth rate of urban population is $3.79 \%$ from 2001 to 2011 which is lower compared to stage - I \& II. The urban population in China is $51.20 \%$ in 2011 and it has $117^{\text {th }}$ position in terms of percentage of urban population as per

Fig-5 Bar diagram of urban population from 2001 to 2011

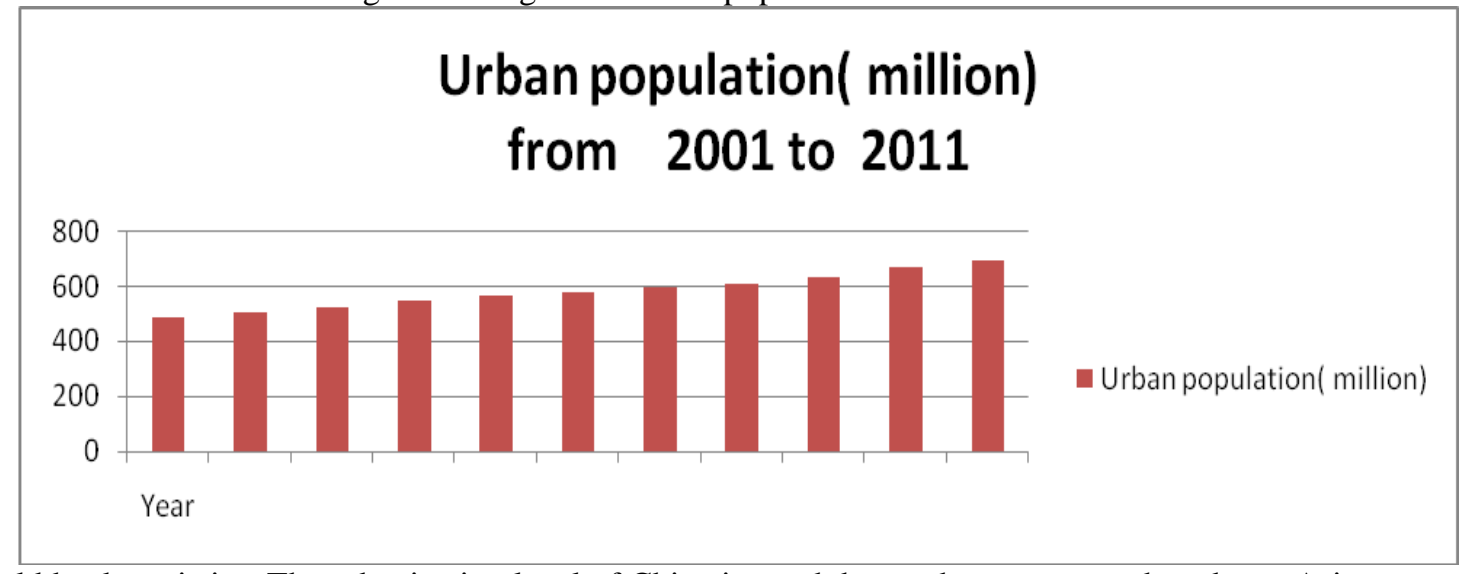

World bank statistics. The urbanization level of China is much better than many south and east Asian countries. The average per capita real GDP growth rate is $9.82 \%$ with standard deviation of 0.94 during this period( Table-3). The bar diagram of urban population during this period is shown in fig-5.

\section{Least Square Trend Equation during stage-III}

Simple least square trend equation during 2001 to 2011 with the help of data gives following equation.

$\mathrm{Y}=462.63+19.54 \mathrm{t}$

$\left(\mathrm{t}=25.97, \mathrm{SE}=0.75, \mathrm{R}^{2}=0.99\right)$

The coefficient is 19.54 in stage-III which is higher than the least square coefficient(14.21) in stage-II and 11.35 in stage-I.

\section{Urbanisation and Growth Linkage during Stage-III}

The urbanization and growth linkage is academically interesting and it has been calculated in almost all countries of the world. There exist positive relation between them but it is not significant in first two stages but it was negative in third stage in China. The regression equation is as follows.

$\mathrm{UG}_{\mathrm{t}}=7.91-0.42 \mathrm{GGDP}_{\mathrm{t}}$

$\left(\mathrm{t}=-1.04, \mathrm{SE}=0.40, \mathrm{R}^{2}=0.11\right)$

The negative relation during this stage is also not significant. The line graph of growth rates is shown below in fig-6. 
Fig-6 Line graph of growth rates of urban population and per capita GDP

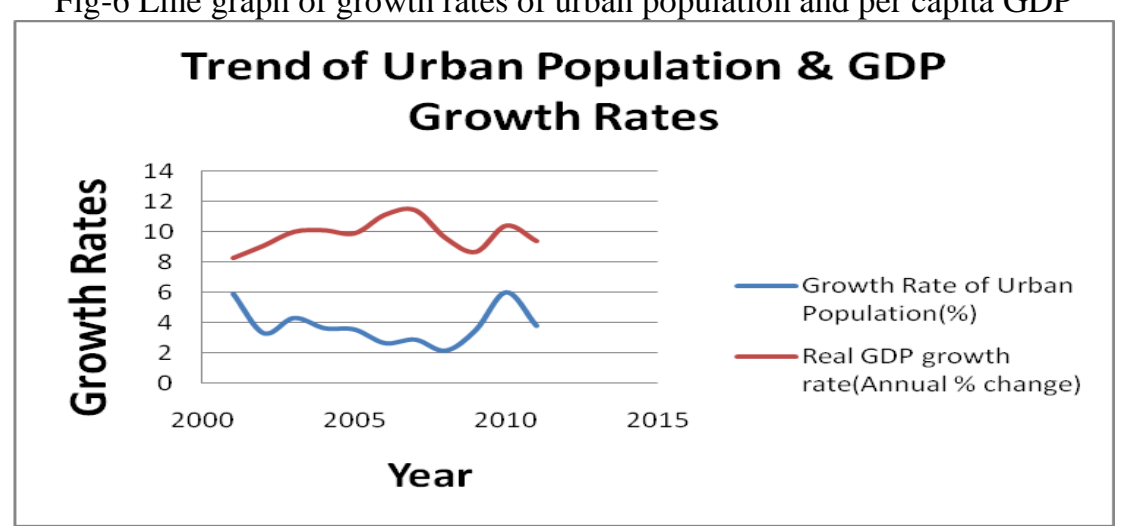

Urbanization in China from 1978 to 2011

The urbanization in China has been rapid during last 34 years but there is no significant relationship between growth rates of urbanization and GDP. Urbanization and growth go together and no country has ever reached middle-income status without a significant population shift into cities. Urbanization is necessary to sustain growth in developing countries, and it yields other benefits as well. But it is not necessarily drive to growth.

Fig-7 Line graph of Growth rates of urban population \& per Capita real GDP

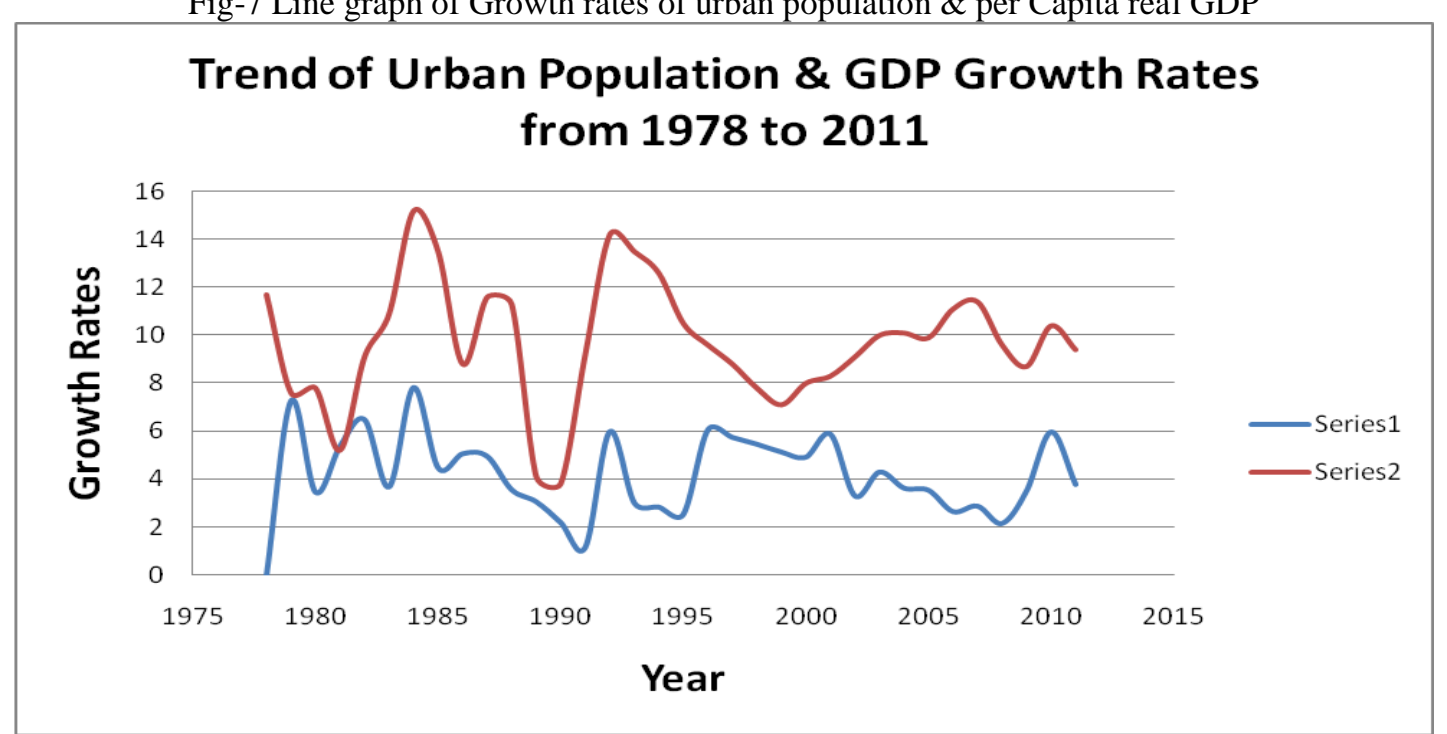

\section{Granger causality Wald tests}

Linkage between Growth rates of urban population and Per Capita GDP during entire period of study from 1978 to 2011 was examined through Granger causality Wald tests. It is found that there is significant unidirectional effect of growth of per capita GDP on growth of Urban population as shown below in table-4.

Table-4 Results of Granger causality Wald tests using pooled data from 1978 to 2011

\begin{tabular}{|l|l|l|l|}
\hline Variable & Chi square & Prob>Chi Square & $\begin{array}{l}\text { MacKinnon approximate } \\
\text { p-value for Z(t) }\end{array}$ \\
\hline Growth of Urbanisation & $\mathbf{0 . 4 8 5}$ & $\mathbf{0 . 7 8 5}$ & $\mathbf{0 . 0 0}$ \\
\hline Growth of PGDP & 2.41 & 0.299 & $\mathbf{0 . 0 1 5}$ \\
\hline
\end{tabular}

\section{Conclusion}

Chinese urbanization demonstrates complex and contradictory but complementary aspects of state control and increasing market formation, development and influence. The Urbanization in China in the postreform period since 1978 is remarkable for hukou system, household responsibility, land reform, tax-sharing, housing reform and influential national policy. The state continues to have an important role in determining the pace of urbanization and shaping urban and regional growth patterns. Three distinctive stages of urbanization identified and discussed are strongly influenced by policies on enterprises, land and housing reform, market 
forces, and rising per capita income. The key factors affecting the processes of urbanization and urban development are different in each stage. There is positive but insignificant linkage between growth of urban population and GDP growth rates.

\section{References}

[1] Cartier, C. (2001), Zone fever, the arable land debate, and real estate speculation: China's evolving land use regime and its geographical contradictions, Journal of Contemporary China, Vol 10, No 28, p- 445-469.

[2] Chan, K.W. (1994), Urbanization and rural-urban migration in China since 1982: a new base line, Modern China, Vol 20, No 3, p243-281.

[3] Chan, K.W. (2009), The Chinese Hukou system at 50, Eurasian Geography and Economics, Vol 50, No 2, p- $197-221$.

[4] Chan, K.W. and Y. Hu (2003), Urbanization in China in the 1990s: new definition, different series, and revised trends, The China Review, Vol 3, No 2, p-49-71.

[5] Chan, K.W. and X. Xu (1985), Urban population growth and urbanization in China since 1949: reconstructing a base line, The China Quarterly, 104, p- 583-613.

[6] Chan, K.W. and L. Zhang (1999), The Hukou system and rural-urban migration in China: processes and changes, The China Quarterly, 160, p- 818-855.

[7] Chang, C., B.P. McCall et al. (2003), Incentive contracting versus ownership reforms: evidence from China's township and village enterprises, Journal of Comparative Economics, Vol 31, No 3, p-414-428.

[8] Ding, C. (2003), Land policy reform in China: assessment and prospects, Land Use Policy, Vol 20, No 2, p- $109-120$.

[9] Dowall, D.E. (1993), Establising urban land markets in the People "s Republic of China, Journal of The American Planning Association, Vol 59, No 2, p- 182-192.

[10] Friedmann, J. (2004), China's Urban Transition. Minneapolis, University of Minnesota Press, Minneapolis.

[11] Ghose, A.K. (2005), Employment in China: Recent Trends and Future Challenges. Retrieved 24 January, 2013 from http://www.ilo.org

[12] Kung, J.K.S. and Y.M. Lin (2007), The decline of township and village enterprises in China's economic transition, World Development, Vol 35, No 4, p- 569-584.

[13] Liang, X. (2006), The evolution of township and village enterprises (TVEs) in China, Journal of Small Business and Enterprise Development, Vol 13, No 2, p-235-241.

[14] Lin, G.C.S. (2007), Reproducing spaces of Chinese urbanisation: new city-based and land-centred urban transformation, Urban Studies, Vol 44, No 9, p- 1827-1855.

[15] Liu, A.P.L. (1992), The Wenzhou model of development and China modernization, Asian Survey, Vol 32, No 8, p- 696-711.

[16] Ma, L.J.C. and M. Fan (1994), Urbanization from below: the growth of towns in Jiangsu, China, Urban Studies, Vol 31, No 10, p$1625-1645$

[17] Ma, L.J.C. and C.S. Lin (1993), Development of towns in China: a case study of Guangdong Province, Population and Development Review, Vol 19, No 3, p- 583-606.

[18] Oi, J.C. (1995), The role of the local state in China's transitional economy, The China Quarterly, 144, p- 1132-1149.

[19] Shen, J. (1995), Rural development and rural to urban migration in China, 1978-1990, Geoforum, Vol 26, No 4, p- 395-409.

[20] Shen, X.P. and L.J.C. Ma (2005), Privatization of rural industry and de facto urbanization from below in Southern Jiangsu, China, Geoforum, Vol 36, No 6, p- 761-777.

[21] Wang, Y.P. (2001), Urban housing reform and finance in China: a case study of Beijing, Urban Affairs Review, Vol 36, No 5, p620-645.

[22] Wu, F. (1996), Changes in the structure of public housing provision in urban China, Urban Studies, Vol 33, p- 1601-1627.

[23] Wu, F. (2001), China's recent urban development in the process of land and housing marketization and economic globalization, Habitat International Vol 25, p- 273-289.

[24] Xie, L. (2010), Promoting Employment: The Prior Goal on Social and Economic Development. Retrieved on 23 January, 2013 from http://www.financialnews.com.cn Xu, J. (2008), Governing city regions in China: theoretical discourses and perspectives for regional strategic planning, Town Planning Review, Vol 79, Nos 2-3, p- 157-185.

[25] Xu, J. and Ng, M.K. (1998), Socialist urban planning in transition: the case study of Guangzhou, China, Third World Planning Review, Vol 20, No 1, p- 35-51. 